\title{
Formulasi Pakan Ayam Arab Petelur dan Pembuatan Imbuhan Pakan Berbasis Sumber Daya Lokal di Kabupaten Aceh Besar
}

\section{Feed Formulation for Laying Hens and Feed Additive Production Based on Local Resources in Aceh Besar}

\author{
Samadi $^{1, a}$ Sitti Wajizah ${ }^{1}$ dan Fitrah Khairi ${ }^{1}$ \\ ${ }^{1}$ Fakultas Pertanian, Universitas Syiah Kuala, Banda Aceh \\ aemail: samadi177@unsyiah.ac.id
}

\begin{abstract}
Abstrak
Peternakan merupakan bagian integral dari bidang pertanian yang merupakan salah satu bidang andalan dalam menopang perekonomian masyarakat pedesaan yang berbasis kepada perekonomian. Pentingnya sektor peternakan berkaitan dengan peningkatan taraf hidup masyarakat, selanjutnya untuk meningkatkan produktivitas ternak perlu dilakukan pembuatan pakan dengan formulasi yang baik dan seimbangan dalam arti pemenuhan kebutuhan akan nutrisi ternak, untuk meningkatkan system kekebalan tubuh ternak dapat dilakukan dengan pemberian probiotik. Kegiatan pengabdian masyarakat berbasis produk yang dilaksanakan di Desa Manggra, Mukim Meureu, Kecamatan Indrapuri Kabupaten Aceh Besar dalam pembuatan formulasi ransum untuk pakan ayam petelur, dan di Desa Tumbo Baro Kecamatan Kuta Malaka Kabupaten Aceh Besar dalam pembuatan probiotik untuk ternak unggas. Kegiatan diawali dengan survei dan pemetaan masalah, dilanjutkan pelaksanaan yang terdiri dari tahap persiapan, tahap pembekalan, tahap workshop dan pelaksanaan pembuatan formulasi ransum dengan berbagai jenis bahana pakan yang tersedia dan pembuatan probiotik untuk ternak unggas. Pengolahan pakan yang bersumber dari limbah dan industri pertanian. Tahapan utama dari kegiatan ini berupa tahap perencanaan dan pengolahan ransum yang dilakukan oleh fasilitator dan masyarakat. Tahap akhir kegiatan ini adalah melakukan monitoring dan peninjauan langsung terhadap produktivitas ternak dari forrmulasi ransum yang dibuat dan probiotik yang diproduksi. Kegiatan ini berhasil meningkatkan produktivitas ternak, pemahaman dan partisipasi masyarakat tentang pembuatan formulasi ransum dan produksi probiotik
\end{abstract}

Kata Kunci: formulasi, ransum, probiotik, pakan, ayam

\begin{abstract}
The livestock is an integral part of agriculture which is one of the mainstay fields in supporting the economy of rural communities based on the economy. The importance of the livestock sector is related to improving the standard of living of the community, then to improve livestock productivity it is necessary to make feed with a good formulation and balance in the sense of meeting the needs for livestock nutrition, to improve the animal's immune system can be done by providing probiotics. The activities of community service based on Product in Manggra Village, Mukim Meureu, Indrapuri District, Aceh Besar Regency in the formulation of rations for laying hens, and in Tumbo Baro Village, Kuta Malaka District, Aceh Besar Regency in making probiotics for poultry. The activity began with a survey and mapping of the problem, followed by the implementation which consisted of the preparatory stage, the debriefing phase, the workshop phase and the implementation of ration formulation with various types of feed ingredients available and the making of probiotics for poultry. The processing of feed sourced from waste and agricultural industries. The main stage of this activity is in the form of planning and processing of the ration carried out by the facilitator and the community. The final stage of this activity is to conduct monitoring and direct observation of livestock productivity from the formulation of rations made and probiotics produced. This activity has succeeded in increasing livestock productivity, understanding and community participation in ration formulation and probiotic production
\end{abstract}

Keywords: formulation, ration, probiotics, feed, chicken 


\section{Pendahuluan}

Salah satu faktor yang mempengaruhi produktivitas dan reproduktivitas ternak adalah pakan disamping faktor lain seperti genetik, pengontrolan terhadap penyakit dan faktor lingkungan lainnya. Salah satu contoh dari peran pakan yang mempengaruhi produksi dari ternak adalah kandungan asam-asam amino esensial (Samadi dan Liebert, 2007a; 2007b dan 2008). Pakan merupakan biaya terbesar yang dikeluarkan oleh peternak mencapai $60-70 \%$ dari total biaya produksi ternak. Oleh karena itu, dalam memformulasikan pakan ternak, para peternak tidak hanya terfokus pada kualitas pakan (kandungan nutrisi) yang dihasilkan, tetapi juga harga dari masing-masing bahan pakan yang digunakan.

Daerah Aceh sebenarnya kaya akan bahan pakan lokal yang bisa dimanfaatkan untuk ransum ternak. Sentuhan teknologi berupa teknik formulasi ransum ayam (petelur baik ras maupun non ras) dan juga kandungan nutrisi (berdasarkan kebutuhan ternak) maka bahan pakan yang dihasilkan bisa bersaing dengan produk bahan pakan komersial. Dalam penyusunan ransum ini aspek ekonomi berkaitan dengan bahan baku yang yang digunakan perlu mendapat perhatian khusus, sehingga harga pakan yang dihasilkan lebih murah dari harga bahan pakan komersial tampa mengurangi kualitas yang dari pakan yang dihasilkan.

Berbagai sumber bahan pakan lokal seperti dedak, jagung, tepung ikan, bungkil kelapa dan bungkil kedelai dan berbagai sumber bahan pakan lainnya yang dapat dimanfaatkan dengan teknologi penyusunan ransum berkualitas dengan harga yang lebih rendah dari ransum komersial. Selama ini sebagian bahan baku pembuatan pakan ayam di Sumatra Utara juga didatangkan dari Aceh dengan demikian terjadi peningkatan harga berkaitan dengan biaya angkutan dan lain sebagainya. Formulasi pakan sendiri tentu dapat menekan biaya yang akan dikeluarkan oleh peternak, sehingga pendapatan peternak menjadi meingkat.

Indra Jaya Unggas adalah salah satu usaha dibidang peternakan ayam ayam arab petelur yang didirikan pada tahun 2015 oleh alumni Program Studi Peternakan Fakultas Pertanian Unsyiah dengan ketua M. Yasir, S.Pt dan beraggotakan beberapa orang alumni Program Studi Peternakan Unsyiah. Lokasi usaha tersebut terletak di Desa Manggra, Mukim Meureu, Kecamatan Indrapuri Kabupaten Aceh Besar. Pada awal usaha tersebut dikelola secara perseorangan.

Pada awal pendirian usaha Indra Jaya Unggas memiliki ayam petelur arab 200 ekor dan saat ini jumlahnya menjadi 700 ekror dengan produksi telur 450 butir per hari. Luas kandang usaha adalah $8 \times 30 \mathrm{~m}^{2}$. Tipe kandang yang digunakan adalah model batre. Daya tampung kandang adalah 2.000 ekor. Untuk konsumsi pakan per hari sebanyak 900 gr/ekor/hari, atau setara dengan 1 karung pakan per hari untuk total pakan keseluruhan yang habis dikonsumsi. Lokasi pasar jual produk yaitu warung-warung sekitar, masyarakat dan pasar yang ada di kawasan indrapuri dan samahani.

Peluang usaha ini sangat besar karena pesaing dibidang ini masih sedikit. Pemilik usaha ingin memperluas usahanya namun terlendala di modal yang masih kurang. Namun dalam perkembangan usaha ini memiliki kendala diantaranya harga pakan yang terus meningkat, sehingga keuntungan menjadi menjadi rendah dan pakan sangat tergantung dari luar daerah Aceh.

Permasalahan mitra kelompok Indra Jaya Unggas adalah: a) peralatan pembuatan pelet yang belum ada, b) penggunaan bahan pakan komersial dengan harga tinggi sehingga mengurangi pendapatan peternak c) formulasi pakan yang belum optimal dan perlu untuk ditingkatkan, dan d) pengemasan pakan yang tidak memenuhi standard.

Informasi yang berkaitan dengan penggunaan bahan pakan lokal sebagai sumber bahan pakan ternak yang masih minim. Sementara berbagai bahan pakan lokal yang tersedia sangat memungkinkan untuk digunakan sebagai pakan ayam petelur arab yang dapat menurunkan biaya produksi. Dengan teknik formulasi pakan diharapkan dapat membantu mitra Indra Jaya Unggas untuk menekan biaya produksi yang dikeluarkan dalam jumlah yang besar selama ini. 


\section{Materi dan Metode Pelaksanaan}

Metode pendekatan yang dilaksanakan untuk menyelesaikan persoalan mitra dengan program yang telah disepakati bersama adalah untuk mendukung realisasi program Pengabdian Masyarakat Berbasais Produk. Pelaksanaan kegiatan ini dilakukan dengan 2 (dua) metode, yaitu: (1) metode pendidikan atau penyuluhan, dan (2) pendidikan di lapangan (demonstrasi/pelatihan).

Pada metode pendidikan di kelas, kelompok kelompok Indra Jaya Unggas diberi pengetahuan tetang segala hal yang berkaitan dengan pembuatan bahan pakan ternak unggas mulai dari pemilihan bahan pakan lokal, formulasi ransum dan pemasaran. Sehingga kelompok Indra Jaya Unggas benar-benar memahami tentang hal yang berakitan dengan formulasi pakan. Selain itu juga dilakukan pretest dan post test terhadap kelompok Indra Jaya Unggas tentang hal yang berkaitan dengan pakan ternak ternasuk kualitas terutama bahan pakan ternak lokal, formulasi ransum dan juga hal yang berakitan dengan manajemen pemeliharaan ternak ayam arab. Tujuan pemberian pre dan pest test ini agar pengetahuan dan ketrampilan kelompok sasaran sebelum dan sesudah dilakukan pembinaan.

\section{Pembuatan Formulasi Pakan}

Pakan merupakan salah satu komponen penting dalam industri perunggasan. Melonjaknya harga pakan menjadi masalah bagi usaha peternakan, karena biaya ransum mencapai $70-80 \%$ dari total biaya pemeliharaan. Bahan ransum unggas yang harus di impor merupakan salah satu penyebab terpuruknya usaha perunggasan, maka dalam hal ini kami mencoba melakukan pembuatan ransum dengan melakukan formulasi dari berbagai bahan yang tersedia.

Berikut merupakan jenis bahan pakan yang digunakan dalam formulasi pakan yang dibuat dalam kegiatan pengabdian.

Pada Tabel 1 dapat dilihat komponen dari formulasi ransum yang dibuat, yang terdiri dari bahan pakan sumber protein, bahan pakan sumber energi dan bahan pakan sumber mineral yang dibuat dalam suatu formulasi untuk memperoleh kandungan nutrisi yang sesuai dengan kebutuhan ayam petelur.

Tabel 1. Bahan Pakan yang Digunakan dalam Formulasi Ransum Ayam Arab Petelur

\begin{tabular}{|c|c|c|c|c|c|c|}
\hline$\overline{\text { Code }}$ & Ingredient name & Amount & $\%$ Dry matter & $\%$ As fed & Cost/Kg. & Value \\
\hline 2 & Corn & 60.321 & 60.321 & 60.321 & 5.300 & 319.703 \\
\hline 20 & Raw rice bran & 6.325 & 6.325 & 6.325 & 5.500 & 34.785 \\
\hline 24 & Palm kernel meal & 1.000 & 1.000 & 1.000 & 3.000 & 3.000 \\
\hline 30 & Soybean meal $44 \%$ & 15.878 & 15.878 & 15.878 & 10.400 & 165.131 \\
\hline 41 & Fish meal 58\% & 7.326 & 7.326 & 7.326 & 19.100 & 139.926 \\
\hline 51 & DL-Methionine & 0.086 & 0.086 & 0.086 & 160.000 & 13.783 \\
\hline 62 & Dicalcium phosphate & 0.818 & 0.818 & 0.818 & 10.500 & 8.584 \\
\hline 65 & Calcium carbonate & 8.111 & 8.111 & 8.111 & 2.000 & 16.221 \\
\hline 70 & Salt & 0.136 & 0.136 & 0.136 & 2.500 & 0.340 \\
\hline & Total & 100.000 & 100.000 & 100.000 & & 701.473 \\
\hline
\end{tabular}

Keterangan: Jenis Bahan Pakan yang akan di Formulasi 
Pembuatan Probiotik sebagai Campuran Air Minum Unggas

Bahan-Bahan :

1. Air Bersih $=8$ liter.

2. Yakult $=2$ botol.

3. Ragi Tape $=1$ butir

4. Molasses (Tetes Tebu / Gula Jawa / Gula Merah) $=1 \mathrm{~kg}$.

5. Air Kelapa Murni (dari 1 butir buah kelapa yang sudah tua)

6. Jerigen 10 liter $=1$ unit

\section{Prosedur Kerja}

\section{Cara Mengolah Bahan Probiotik Rabal :}

1. Disiapkan air bersih sebanyak 8 liter dan dimasukkan ke dalam Jerigen bersih,

2. Membuat campurkan larutan air kelapa, molases, ragi tape yang telah dihaluskan dan yakult sebagai sumber probiotik yang akan dikembangkan ke dalam Jeringen yang telah berisi air bersih.

3. Larutan yang telah dicampurkan dengan air bersih di aduk agar semua bahanbahan terlarut merata.

4. Larutan yang sudah teraduk rata dilakukan penyimpanan secara anaerob, dimana pada bagian atas jerigen dibuat saluran pembuangan gas hasil fermentasi yang disalurkan melalui penampungan yang berisi air agar udara dari luar tidak masuk kedalam silo

Larutan tersebut disimpan selama 7 hari agar terjadi proses fermentasi dengan sempurna yang akan di tandai dengan cairan di dalam jerigen berubah warna menjadi coklat dan berbau alkohol.

\section{Hasil dan Pembahasan}

\section{Kandungan Nutrisi Pakan dengan Metode Formulasi}

Kandungan nutrisi ransum ayam arab petelur dapat dilihat pada Table 2 .

Pemberian ransum yang tepat dapat meningkatkan produksi telur. Ransum ayam petelur harus diperhitungkan kandungan nutrisinya terutama kandungan protein. Ransum komersil layer mempunyai kadar protein kasar sekitar 22\% (SNI, 2006), sedangkan berdasarkan NRC (1994) standar kebutuhan nutrisi untuk ayam petelur fase layer minimal $16 \%$, sedangkan energi metabolisme $2850 \mathrm{kcal} / \mathrm{kg}$. Ransum komersial harganya cukup tinggi dan

Tabel 2. Kandungan Nutrisi Pakan Formulasi

\begin{tabular}{cllrrr}
\hline Code & Nutrient name & Unit & Calculated & Minimum & Maximum \\
\hline 1 & ME. for Poultry & Cal/Kg. & 2.758 .860 & 2.750 .000 & 2.900 .00 \\
3 & Protein & $\%$ & 17.005 & 17.000 & 19.00 \\
6 & Fat & $\%$ & 4.030 & 4.000 & 7.00 \\
7 & Fiber & $\%$ & 3.475 & 3.000 & 6.00 \\
8 & Calcium & $\%$ & 3.893 & 3.900 & 4.20 \\
9 & Total Phosphorus & $\%$ & 0.704 & 0.700 & \\
10 & Avail. P for Poultry & $\%$ & 0.410 & 0.400 & \\
12 & Salt & $\%$ & 0.295 & 0.300 & 0.55 \\
13 & Arginine & $\%$ & 1.078 & 0.850 & \\
18 & Lysine & $\%$ & 0.908 & 0.800 & \\
19 & Methionine + Cystine & $\%$ & 0.661 & 0.660 & \\
20 & Methionine & $\%$ & 0.416 & 0.340 & \\
23 & Threonine & $\%$ & 0.649 & 0.580 & \\
24 & Tryptophan & $\%$ & 0.192 & 0.180 & \\
\hline
\end{tabular}

Keterangan : Hasil Formulasi Pakan untuk Ayam Arab Petelur menggunakan Software FeedLive 
kemungkinan dapat terjadi kelebihan protein yang akan dibuang melalui ekskreta, sehingga pengeluaran untuk produksi ayam menjadi tinggi. Kemampuan adaptasi saluran pencernaan berdasarkan atas fungsi fisiologis tergantung pada pasokan nutrisi yang diberikan pada perkembangan awal, status nutrisi dan pola pemberian pakan dapat memodifikasi fungsi saluran cerna (Suthama dan Ardiningsasi, 2012).

\section{Produksi Telur Ayam Arab dalam Kegiatan Pengabdian}

Produksi telur yang diperoleh selama kegiatan pengabdian masyarakat dapat dilihat pada Tabel 3. Pada Tabel 3 dapat dilihat produksi telur yang dihasilkan dengan pemberian ransum yang di formulasikan sendiri terjadinya fluktuasi jumlah yang dihasilkan, pada minggu pertama dengan formulasi pakan yang diberikan tidak memberikan dampak penurunan produksi dari sebelumnya, tetapi pada minggu selanjutnya terjadi penurunan produksi telur, hal ini diduga karena adanya pengaruh dari pergantian ransum yang diberikan kepada ternak tersbut, ternyata pada minggu selanjutnya produksi terlur mulai terjadi peningkatan hal ini diduga ternak telah melalui masa adaptasi terhadap pakan baru yang diberikan sehingga produksi telur kembali stabil dan terjadi peningkatan dari sebelumnya.

Jumlah telur yang dihasilkan ayam arab tersebut berada pada masa akhir produksi, sehingga ayam hanya mampu menghasilkan produksi telur dengan persentase yang lebih kecil. Banyaknya jumlah telur sesuai dengan pendapat Wahyu (2004), yang menyatakan bahwa pada umur 22 minggu produksi telur naik dengan tajam dan mendapat puncaknya pada umur 38-40 minggu, kemudian produksi telur menurun dengan perlahan sampai $65 \%$ sesudah masa produksi 15 bulan yaitu pada umur ayam 82 minggu.

Kuantitas dan kualitas pakan yang diberikan sangat menentukan terhadap produksi dan kualitas telur baik secara fisik/ekternal maupun secara kimiawi/internal. Produksi dan kualitas telur akan tercapai secara maksimal apabila kualitas pakan yang diberikan mencukupi sesuai umur dan tatalaksana pemeliharaan dan akan tercapai secara efisien apabila tersedia pakan murah dengan kandungan nutrisi yang dapat memenuhi kebutuhan ayam (Tugiyanti dan Iriyanti, 2012).

Blakely dan Blade (1991) menyatakan bahwa untuk ayam petelur produksi telur ratarata yang baik adalah 20 butir per bulan. Zulfikar, (2013) kemampuan ayam petelur berproduksi tinggi akan menghasilkan rata-rata 250 butir telur perekor pertahun dengan berat kira-kira mencapai $60 \mathrm{~g}$. Produksi telur ayam petelur pada tahun-tahun berikutnya cenderung akan terus menurun (Priyatno, 2000). Periode produksi ayam petelur terdiri dari dua periode yaitu fase I dari umur 22-42 minggu dengan rata-rata produksi telur $78 \%$ dan berat telur $56 \mathrm{~g}$, fase II umur 42-72 minggu dengan rata-rata produksi telur $72 \%$ dan bobot telur $60 \mathrm{~g}$ (Scott, et al., 1982).

Tabel 3. Rata-rata Produksi Telur yang Diperoleh

\begin{tabular}{cccccc}
\hline \multirow{2}{*}{ Bulan } & \multicolumn{4}{c}{ Rata-rata Produksi Telur (\%) } & \multirow{2}{*}{ Produksi Rataan } \\
\cline { 2 - 5 } & Minggu ke-1 & Minggu ke-2 & Minggu ke-3 & Minggu ke-4 & $\mathbf{3 7 . 8 6}$ \\
\hline Mei & & & 42.00 & 33.71 & $\mathbf{3 7 . 7 9}$ \\
Juni & 25.71 & 33.43 & 44.57 & 47.43 & $\mathbf{4 4 . 8 6}$ \\
Juli & 44.00 & 45.43 & 44.57 & 45.43 & $\mathbf{4 4 . 8 6}$ \\
Agustus & 46.29 & 46.29 & 42.00 & & \\
\hline
\end{tabular}

Keterangan: Hasil Produksi Telur yang Diperoleh Selama Pengamtan dengan Pemberian Ransum Hasil Formulasi 


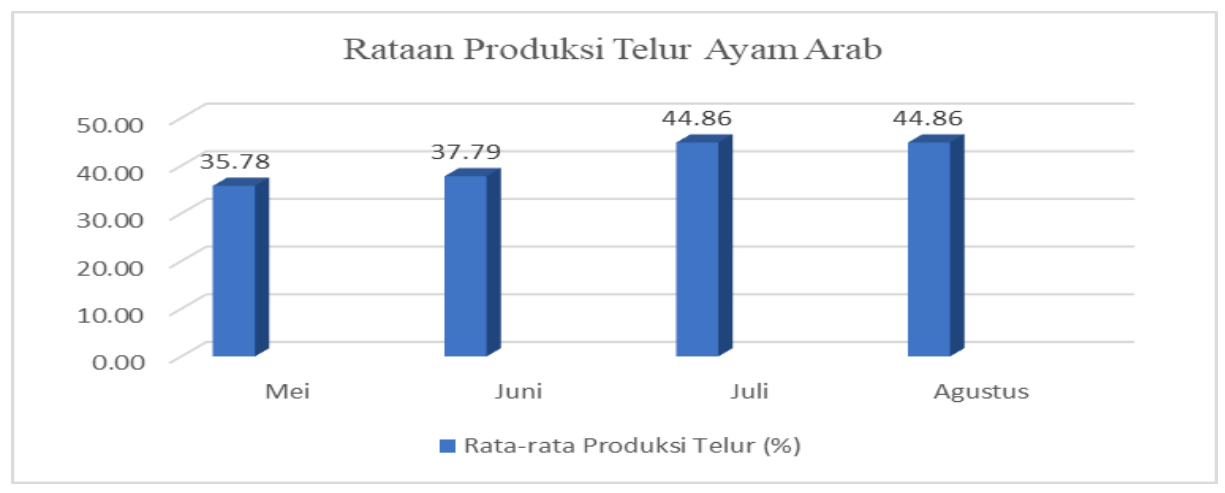

Gambar 1. Rata-rata Produksi Telur yang Diperoleh dengan Pemberian Pakan Hasil Formulasi Ransum yang Diproduksi

Hasil pengamatan yang dilakukan diperoleh rata-rata persentase jumlah telur ayam Arab pada bulan pertama sebesar $35,78 \%$, bulan ke-2 (Juni) 37,79\%, bulan ke-3 (Juli) 44,86\% dan pada bulan Agustus produksi telur yang diperoleh sebesar 44,86\%. Hasil tersebut menunjukkan bahwa rata-rata persentase jumlah telur ayam Arab terjadinya peningkatan dengan penggantian ransum yang diberikan.

Amrullah (2003), menyatakan bahwa petelur unggul dapat berproduksi sampai $70 \%$ atau 275 butir pertahun. Produksi telur ayam lokal di Indonesia dengan makanan yang baik juga berkisar dari 40-50\%. Ayam Arab betina mulai bertelur pada umur 5 bulan dengan masa puncak produksi di atas umur 8 bulan, sehingga dalam setahun ayam Arab dapat menghasilkan telur hingga 250-300 butir per tahun.

Tabel 4. Hasil Analisa Kandungan Khamir dan Bakteri Asam Laktat (BAL) yang terdapat pada Probiotik yang di Produksi

\begin{tabular}{|c|c|c|c|c|}
\hline \multicolumn{2}{|c|}{$\begin{array}{l}\text { Total Khamir } \\
\text { (CFU/ml) }\end{array}$} & \multicolumn{3}{|c|}{ Total BAL $(\mathrm{CFU} / \mathrm{ml})$} \\
\hline $10^{4}$ & $10^{5}$ & $10^{6}$ & $10^{7}$ & $10^{8}$ \\
\hline 124 & 32 & 193 & 18 & 2,5 \\
\hline \multicolumn{5}{|c|}{$\begin{array}{l}\text { Keterangan: Hasil Analisis Laboratorium Ilmu } \\
\text { dan Teknologi Pengolahan Susu } \\
\text { Penghitungan koloni bakteri dilakukan } \\
\text { dengan mengamati semua koloni yang tumbuh } \\
\text { pada permukaan media agar yang digunakan. } \\
\text { Berdasarkan hasil pengujian menggunakan }\end{array}$} \\
\hline
\end{tabular}

metode TPC, jumlah bakteri yang dapat dihitung mulai dari pengenceran tingkat $10^{6}$ sebesar 193 x $10^{6} \mathrm{CFU} / \mathrm{ml}$, pengenceran $10^{7} 18 \times 10^{7}$ $\mathrm{CFU} / \mathrm{ml}$ dan pengenceran $10^{8}$ sebesar $2,5 \times 10^{8}$. Semntara jumlah khamir yang dapat dihitung mulai dari pengenceran tingkat $10^{4}$ sebesar $124 \times 10^{4} \mathrm{CFU} / \mathrm{ml} 10^{5}$ sebesar $32 \times 10^{5} \mathrm{CFU} / \mathrm{ml}$.

Pertumbuhan BAL meliputi proses yang kompleks, diawali dengan masuknya nutrisi ke dalam sel, kemudian nutrisi diubah menjadi organel sel. Selanjutnya digunakan untuk replikasi kromosom, setelah itu terjadi pembelahan sel menjadi dua sel anakan, kemudian terjadi peningkatan jumlah dan ukuran sel (Moat et al., 2002). Pelczar et al.,(1993) menyatakan gula merupakan nutrient utama sel yang digunakan untuk respirasi sel atau sumber energi utama. Metabolisme dapat menghasilkan glukosa yang diperlukan untuk kerja sel, sintesis organel sel dan untuk membentuk generasi baru.

Hasil fermentasi Probiotik ini diklaim tidak berbahaya, karena sifat bakteri lactobacillus dan yeast adalah membantu mengurai makanan, yang dapat dicerna dengan baik oleh usus ayam sehingga pakan yang terserap dapat maksimal untuk produksi daging maupun telur dengan meningkatnya nafsu makan ayam. Pemberian probiotik dapat menjaga keseimbangan mikroorganisme dalam system pencernaan ternak, sehingga akan memeperbaiki proses pencernaan, daya cerna bahan pakan, penyerapan zat-zat nutrisi akan meningkat dan mampu menjaga kesehatan ternak (Agustina et al., 2007) 


\section{Kesimpulan}

Kegiatan pengabdian yang dilaksanakan dengan pembuatan ransum ayam arab petelur dan pembuatan imbuhan pakan berbasis sumber daya lokal dapat diterapkan dengan baik pada peternakan unggas dan dapat mempertahankan tingkat produksi dari unggas itu sendiri dan memberi manfaat bagi peternak sehingga dapat diterapakan secara berkesinambungan.

Tabel 5. Hasil Analisis Kuesioner Pre-test dan Post-test.

\begin{tabular}{clcc}
\hline \multirow{2}{*}{ No. } & \multicolumn{1}{c}{ Jenis Pengetahuan } & \multicolumn{2}{c}{ Tingkat Pengetahuan (\%) } \\
\cline { 3 - 4 } & & $\begin{array}{c}\text { Sebelum } \\
\text { Kegiatan Pengabdian }\end{array}$ & $\begin{array}{c}\text { Setelah } \\
\text { Kegiatan Pengabdian }\end{array}$ \\
\hline 1 & Kebutuhan nutrisi ayam petelur & 70,50 & 95,00 \\
2 & $\begin{array}{l}\text { Jenis-jenis bahan pakan sumber protein dan } \\
\text { energi untuk ayam petelur }\end{array}$ & 67,50 & 100,00 \\
& Jenis-jenis bahan pakan sumber vitamin dan & 61,50 & 100,00 \\
3 & mineral untuk ayam petelur & 50,50 & 100,00 \\
4 & Pengertian bahan pakan imbuhan & 58,50 & 100,00 \\
5 & Fungsi pakan imbuhan & 30,50 & 100,00 \\
6 & Jenis-jenis pakan imbuhan & 25,00 & 100,00 \\
7 & Cara pembuatan pakan imbuhan & 25,00 & 90,00 \\
8 & Formmulasi ransum ayam petelur & & \\
\hline
\end{tabular}

Berdasarkan Tabel 5 dapat dilihat bahwa kegiatan pengabdian yang dilaksanakan dapat memberikan manfaaat yang lebih kepada masyarakat petani peternak yang menjadi mitra pengabdian di Kabupaten Aceh Besar dengan melihat terjadinya peningkatan tingkat pemahaman materi pengabdian yang dilaksanakan.

\section{Daftar Pustaka}

Agustina, L., Purwanti, S., dan Zainuddin, D. 2007. Penggunaan Probiotik (lactobacillus sp.) Sebagai Imbuhan Pakan Broiler. Seminar Nasional Teknologi Peternakan dan Veteriner. Fakultas Peternakan, Universitas Hasanuddin, Makassar.

Amrullah, I. K. 2003. Nutrisi Ayam Petelur. Lembaga Satu Gunung Budi. Bogor.

Blakely J, Bade DH,. 1991. Ilmu Peternakan. Edisi ke empat. Penerjemah: B. Srigandono. Gadjah Mada University Press, Yogyakarta.

Moat, G.A., W. J. Foster and P.M. Spector. 2002. Microbial Physiology. Fourth edition. Wiley Liss. United States of Amerika.

NRC, 1994. Nutrient Requirements of Poultry. National Academy Press. Washington DC.
Pelczar, J. M., E. S. C. Chan, R. K. Noel dan D. E. Diane. 1993. Microbiology Concept and Application. MC Graw Hill. New York.

Priyatno, MA. 2000. Mendirikan Usaha Pemotongan Ayam. Cetakan ke-3. Penebar Swadaya. Jakarta.

Samadi dan Liebert, F. 2008. Modelling the optimal lysine to threonine ratio in growing chickens depending on age and efficiency of dietary amino acid utilisation. $\mathrm{Br}$ Poult Sci. 2008 Jan;49(1):45-54.

Samadi dan Liebert, F. 2007a. Lysine requirement of fast growing chickensEffects of sex, age, level of protein deposition and lysine efficiency. The Journal of Poultry Science. 44:63-72.

Samadi dan Liebert, F. 2007b. Threonine Requirement of Slow-Growing Male Chickens Depends on Age and Dietary Efficiency of Threonine Utilization. Poultry Science 86(6): 1140 - 1148. 
Scott, M. L., M. C. Neisheim and R. J. Young. 1982. Nutrition of The Chickens. 2nd Ed. Publishing by : M.L. Scott and Assoc. Ithaca, New York

Standar Nasional Indonesia. 2006. SNI01-39292006: Pakan Ayam Ras Petelur (Layer). Badan Standarisasi Nasional. Jakarta.

Suthama, N dan S.M., Ardiningsasi. 2012. Perkembangan Fisiologis Saluran Pencernaan Ayam Kedu Periode Starter. Laporan Penelitian. Fakultas Peternakan, Universitas Diponegoro, Semarang.

Tugiyanti E., dan Iriyanti N. 2012. Kualitas Eksternal Telur Ayam Petelur yang Mendapat Ransum dengan Penambahan Tepung Ikan Fermentasi Menggunakan Isolat Produser Antihistamin. Jurnal Aplikasi Teknologi Pangan. Vol. 1 No. 2. Fakultas Peternakan Universitas Jenderal Soedirman. Purwokerto.

Wahyu. 2004. Ilmu Nutrisi Unggas. Yogyakarta: Gajahmada University Press.

Zulfikar. 2013. Manajemen Pemeliharaan Ayam Petelur Ras. Tesis. Pasca Sarjana Kesehatan Masyarakat Veteriner Unsyiah. Banda Aceh 